\title{
Masculinidades e experiências masculinas em Bernardo Guimarães*
}

\author{
Luciano Mendes de Faria Filho** \\ Matheus da Cruz e Zica***
}

\begin{abstract}
Resumo
Neste trabalho identificamos e analisamos as diferentes facetas da masculinidade apresentadas na obra de um dos mais importantes literatos brasileiros do século XIX: o mineiro Bernardo Guimarães. Sem abandonar as representações de feminilidade, enfocamos como o autor, em suas diversas obras, constrói as relações de gênero e produz representações sobre homens e mulheres, dando especial relevo às experiências de masculinidade. Desse modo, pretendemos, também, contribuir para uma maior compreensão da forma como, no final do século XIX, a literatura teve uma participação na produção de representações e práticas de masculinidade (e de feminilidade) no Brasil.
\end{abstract}

Palavras-chave: Literatura, Masculinidade, Formação.

\footnotetext{
* Recebido para publicação em março de 2010, aceito em maio de 2010. Este trabalho é fruto de reflexões desenvolvidas no âmbito do Grupo de Estudos e Pesquisas em História da Educação (GEPHE), que contou com o apoio do CNPq e da CAPES para sua realização.

** Pós-doutor em Educação, Professor da FaE-UFMG. lucianomff@uol.com.br

****Doutorando em Educação, FaE-UFMG. matheusczica@gmail.com
}

cadernos pagu (34), janeiro-junho de 2010:179-208. 
Experiências masculinas em Bernardo Guimarães

Masculinities and Masculine Experiences in Bernardo Guimarães'

Literary Work

\begin{abstract}
This article aims to identify and analyze different aspects of masculinity presented in the literature of Bernardo Guimarães, an important 19th century Brazilian writer from Minas Gerais. We shall focus how the author, in his literary work, constructs the gender relations and produces representations about men and women, specially the masculine experiences, without forgetting the feminine ones. We intend, in the same way, to contribute to a broader understanding of the participation of literature in the production of representations and practices of masculinity (and of femininity) in late nineteenth-century Brazil.
\end{abstract}

Key Words: Literature, Masculinity, Formation. 


\section{Introdução}

As pesquisas, sobretudo em história da educação, têm utilizado a literatura para chamar a atenção para a construção $e$ estruturação das relações de gênero, acentuando, sobretudo, a experiência feminina (cf. Alves, 2007; Lopes, 1998; Magaldi, 1992). Neste trabalho, sem abandonar as representações de feminilidade, identificamos e analisamos as diferentes facetas da masculinidade apresentadas na obra de um dos mais importantes literatos brasileiros do século XIX: o mineiro Bernardo Guimarães. Pretendemos enfocar como o autor, em suas diversas obras, constrói as relações de gênero e produz representações sobre homens e mulheres, dando especial relevo às experiências de masculinidade. Desse modo, pretendemos contribuir para uma maior compreensão da forma como, no final do século XIX, a literatura colaborou para a produção de representações e práticas de masculinidade (e de feminilidade) no Brasil.

Se, como queria Bourdieu (1995:163), os "homens" são vítimas do privilégio de participar dos jogos de dominação, $e$ como asseverava Welzer-Lang (2004), são vítimas justamente porque não têm opção de não participar dos jogos e disputas que se prestam a organizar o poder $e$ a hierarquização masculina, poderia a literatura servir de porta de entrada para o entendimento dos modos como, nas tramas culturais do século $\mathrm{XIX}$, as masculinidades são constituídas, construídas e dadas a ver? Ao mesmo tempo em que respondemos afirmativamente à essa questão, tentamos demonstrar, nos limites deste texto, a forma pela qual Bernardo Guimarães descreveu/construiu a interiorização das masculinidades nas representações que fez de seus jovens personagens. ${ }^{1}$ A importância da análise dessas representações fica evidente se nos damos conta de "que não há

1 Este trabalho faz parte de um investimento maior de análise da obra de Bernardo Guimarães, dentro do qual já trabalhamos com a questão geracional e com as representações femininas. 
Experiências masculinas em Bernardo Guimarães

prática ou estrutura que não seja produzida pelas representações, contraditórias e afrontadas, pelas quais os indivíduos e os grupos dão sentido a seu mundo" (Chartier, 2002:66).

\section{Da educação dos homens}

Inicialmente, é interessante notar que B. Guimarães, homem escolarizado, constrói poucas possibilidades para os percursos de formação de seus personagens masculinos: ou têm uma educação bastante solta ou são educados nos seminários. Ambas se mostram bastante desastradas. Parece confirmar tal perspectiva $\mathrm{O}$ fato de que, dentre seus personagens masculinos, o que melhor sorte tem, é Elias, d'O garimpeiro, que sabe ler e escrever, sabe matemática e contabilidade, é leitor de Rousseau e sabe em profundidade a história das cavalhadas; no entanto, sobre sua educação nada se diz.

Veja-se, contudo, como foi a educação de alguns de seus outros personagens masculinos. Maurício, personagem título de um dos romances, tendo ficado órfão, foi adotado por Diogo Mendes, o capitão-mor que, posteriormente, transferiu-se para as Minas Gerais. Assim se descreve a sua educação:

Era um belo menino, cheio de vivacidade e inteligência. Interessando-se vivamente pelo órfão, que de dia em dia desenvolvia novos dotes e espírito, e excelentes qualidades de coração, Diogo Mendes o fez entrar para o colégio dos jesuítas, a fim de ser educado para o estado clerical. Aí esteve por três ou quatro anos, durante os quais aqueles padres, apreciando a inteligência clara, o espírito vivaz $e$ penetrante, e a índole audaciosa, que o menino então adolescente ia revelando em sumo grau, achando que ali havia massa para se formar um excelente missionário de Loiola, empregaram grandes esforços em atraí-lo ao seu grêmio. Foi tudo embalde; o menino não havia nascido para a roupeta. Havia nele um elemento, que se opunha diametralmente à obediência passiva, essa condição cordial imposta aos discípulos de S. Inácio. Era um extremo amor 
da independência, uma rebeldia indomável contra todo $e$ qualquer jugo (Maurício:38). ${ }^{2}$

Leôncio, o vilão d'A escrava Isaura, teve a seguinte educação:

Leôncio achara desde a infância nas larguezas e facilidade de seus pais amplos meios de corromper o coração $e$ extraviar a inteligência. Mau aluno e criança incorrigível, turbulento e insubordinado, andou de colégio em colégio, $e$ passou como gato por brasas por cima de todos os preparatórios, cujos exames todavia sempre achava à sombra do patronato. Os mestres não se atreviam a dar ao nobre munífico comendador o desgosto de ver seu filho reprovado (A escrava Isaura:13).

Como jovem rico, seu percurso educacional também foi marcado pela matrícula na escola de medicina, da qual saiu por desinteresse, e na faculdade de direito de Olinda, curso que da mesma forma não concluiu. Em seguida vai para a Europa, onde ao invés de estudar fica passeando e tomando contato com ambientes e figuras poucos recomendáveis socialmente. Para trazê-lo de volta, o pai acena com um bom casamento. Segundo o narrador:

Leôncio mordeu a isca e voltou à pátria um perfeito dândi, gentil e elegante como ninguém, trazendo de suas viagens, em vez de conhecimentos e experiência, enorme dose de fatuidade e petulância e um tão perfeito traquejo da alta sociedade, que o tomaríeis por um príncipe. Mas o pior era que, se trazia o cérebro vazio, voltava com a alma corrompida e o coração estragado por hábitos de devassidão e libertinagem. (A escrava Isaura:14)

2 Daqui em diante utilizaremos muitas citações de trechos das obras de Bernardo Guimarães indicando apenas título e página, no sentido de tornar o texto mais conciso e a leitura mais fluida. As obras estão devidamente citadas ao final deste artigo. 
Experiências masculinas em Bernardo Guimarães

A educação de Gonçalo, d'O Ermitão de Muquém, é marcada pela ausência da direção familiar, numa reiterada representação sobre a educação dos jovens ricos na obra de Guimarães. No romance, a apresentação do personagem se dá da seguinte forma:

Era filho de pais abastados e de família; porém educado à larga, abandonado desde a infância a si mesmo, sempre em meio de más companhias, dotado além de tudo de índole inquieta e fogosa, este rapaz, que poderia ser um homem de bem e útil à sociedade, se uma educação regular tivesse dado salutar direção aos instintos de sua natureza, foi-se tornando um valentão famoso, talhado a molde para as galés ou para o patíbulo.

Gonçalo, que assim se chamava, aplicou-se com ardor desde criança ao manejo de armas de toda a qualidade, a domar animais bravos, a caçar, a nadar, enfim a toda sorte de exercícios do corpo os mais rudes e perigosos.

E de feito neste ponto sua educação foi completa (O Ermitão de Muquém:33).

Eugênio ( $O$ seminarista) saiu de casa aos 9 anos para estudar na cidade vizinha, voltava para casa no fim de semana. Pouco mais de dois anos depois, ele é enviado para o seminário. A mudança do ambiente de casa para o novo regime educativo é descrita como uma passagem do espaço aberto para o fechado.

Eis o nosso herói transportado das livres e risonhas campinas da fazenda paterna para a monótona e austera prisão de um seminário no arraial de Congonhas do Campo, de barrete e sotaina preta, no meio de uma turba de companheiros desconhecidos; como um bando de anus pretos encerrados em um vasto viveiro. (O seminarista:21)

Tal idéia é retomada logo depois, utilizando-se, agora, da idéia do "cenário" onde o artista, ou os padres, traçam ou moldam sua criação (ou criatura). 
Eis o novo cenário, a que havemos transportado o nosso herói. O espetáculo não podia deixar de ser curioso $e$ interessante, e nem a nova fase da vida em que ia entrar deixaria de ter encantos para um menino que tanto gostava das práticas de devoção religiosa, e tão forte tendência mostrava para o misticismo. Contudo, aquele filho do sertão, acostumado a percorrer os campos e bosques da fazenda paterna, não pode a princípio deixar de estranhar a severa reclusão e imprescritível regularidade daquela vida monótona e compassada do seminário. Mas, o gênio pacato e a extrema docilidade de Eugênio, ajudados pela bossa da beatividade ou veneratividade, que tinha muito desenvolvida, fizeram com em menos tempo do que qualquer outro se habituasse e tomasse gosto mesmo pelo seu novo gênero de vida, como se fosse o elemento em que nascera. (O seminarista:23)

Observe-se que, não por acaso, será este menino "pacato" e "dócil" que, ao contrário dos outros que tiveram uma educação desregrada, terá um fim trágico - a loucura -, justamente por não conseguir desvencilhar-se do projeto para ele arquitetado pela família e pela igreja.

\section{Na formação do masculino, o discurso da sexualidade}

Podemos ver indícios das hierarquizações características da masculinidade hegemônica ${ }^{3}$ também no século XIX, testemunhado por Guimarães através de suas histórias. Ao perseguirmos

3 O contexto de masculinidade hegemônica é aquele em que "o desejo e a capacidade de cuidar desaparecem durante a socialização do homem em um mundo em que esse modelo hegemônico faz questão dele ter poder, autonomia, força, racionalidade e repressão das emoções; contexto em que está posta a necessidade dos homens de 'provar e provar-se' sexualmente, privada $e$ publicamente, para confirmar sua própria identidade masculina, e definir-se como "não-maricas"'. Essas informações estão em um interessante artigo sobre o prejuízo causado por essa moral exigente para a saúde dos homens que vivem sob sua influência (cf. Korin, 2001:70). 
trajetórias de crescimento de personagens masculinos, percebemos que essa pressão competitiva ocorria desde muito cedo de acordo com a ótica do escritor. Talvez seja exatamente esta a causa da recorrência dos problemas de indisciplina com os meninos também descritos em suas narrativas. Parecia ser um período onde dos meninos era cobrada uma posição, desde a infância, de autonomia e coragem. ${ }^{4}$

Bernardo Guimarães é mais conhecido, no Brasil, pelos livros O seminarista (1872), O Garimpeiro (1872) e A escrava Isaura (1875). No entanto, ele é autor de uma vasta literatura erótica e satírica, a qual, de modo geral, é pouco conhecida pelos leitores de seus romances. No que se refere à literatura erótica, uma de suas produções mais importantes é o poema $O$ Elixir do Pagé (1875). Nele o eu-lírico abre a poesia lamentando a situação de seu pênis "murcho e cabisbaixo" e acaba relembrando os "tempos gloriosos" de seu "caralho" que:

(...) erguendo o teu vermelho cabeçalho, faminto e arquejante, dando em vão rabanadas pelo espaço, pedias um cabaço!

Um cabaço! Que era este o único esforço, única empresa digna de teus brios;

porque surradas conas e punhetas são ilusões, são petas, só dignas de caralhos doentios (Elixir do Pagé:49-50).

Percebe-se, ao longo do poema, uma obsessão pela virgindade. Mas essa predileção pela virgem ("cabaço") não quer dizer necessariamente exclusividade. Ao longo da poesia não é raro vermos no desejo do beneficiado pelo elixir contra a impotência sexual a vontade de proporcionar ao seu "caralho"

4 Os meninos com freqüência desafiam a autoridade do professor $e$, por isso, são também as maiores vítimas dos castigos escolares no século XIX (Dalcin, 2006). 
"novos combates e vitórias/e mil brilhantes glórias" (Elixir do Pagé:51), inclusive com essas metáforas bélicas:

Vinde, ó putas e donzelas, vinde abrir as vossas pernas ao meu tremendo marzapo, que todas, feias ou belas, com caralhadas eternas porei as cricas em trapo... Graças ao santo elixir que herdei do pajé bandalho, vai hoje ficar de pé o meu cansado caralho! (Elixir do Pagé:51).

Feias ou belas, putas ou donzelas, o caráter marcante no decorrer da leitura do Elixir do Pajé é a preocupação exacerbada com a quantidade. Não parece ser gratuita a recorrência do número mil ao longo da poesia. Portanto, a hierarquia, definida pelo próprio eu lírico - "cabaço"/melhor e "surradas conas"/pior, parece valer apenas de forma secundária. Nos perguntamos, então, por que, afinal, querer tantas "fodas"? Qual é a motivação dessa perseguição incessante? Na verdade, é a estrofe final desta poesia que nos permite esboçar algumas considerações:

Sim, faze que este caralho, por tua santa influência, a todos vença em potência, $e$, com gloriosos abonos, seja logo proclamado vencedor de cem mil conos... E seja em todas as rodas d'hoje em diante respeitado como herói de cem mil fodas, por seus heróicos trabalhos, eleito - rei dos caralhos! (Elixir do Pagé:58). 
Experiências masculinas em Bernardo Guimarães

Ora, o que se percebe, através dessa voz masculina, é que a partir de uma recorrente fala sobre as mulheres durante toda a poesia, em seu final breve há um ligeiro deslocamento de foco para os homens. O que parece estar por detrás dessa perseguição ao sexo oposto, buscado de maneira incansável, é a admiração dos outros homens.

\section{Gênero e geração: onde as mulheres são crianças, os homens já nascem homens?}

No livro A Filha do Fazendeiro há um interessante diálogo entre mãe e filho, um rapaz com idade próxima dos 20 anos:

- Arre também com isso, Eduardo! - disse-lhe ela um dia em tom de branda repreensão; - não mostrarás um dia que és homem? Já vou perdendo a fé contigo... (...)

- Ah! Minha mãe, não fale assim; por que motivo?...

- Porque pensei que eras gente, que tinhas coragem e juízo. Agora vejo que não passas de um maluco e um moleirão; que não tens timbre, nem disposição para nada. (...) tu meu fracalhão, andas aí todo embezerrado e amuado como criança que apanhou bolos, tem que ter ânimo (...) (A Filha do Fazendeiro:80-81).

A mãe repreende o filho por supor que ele estava triste por ter sido abandonado pela amada, que se casara com outro. O que está suposto na pergunta, que perdura e é dirigida, ainda hoje, com freqüência às crianças e aos jovens do sexo masculino, evoca uma dúvida fundamental na constituição das relações de gênero $e$, nelas, das representações que se tem do masculino e do feminino: o que faz dos homens sujeitos masculinos? Afinal, como se mostra que é homem?

De acordo com a mãe (que não é um homem), essa condição está relacionada com "coragem", "timbre", "disposição", "ânimo", "juízo" em oposição a "fracalhão", "moleirão", "embezerrado", "amuado", "criança", "maluco". Essa 
repreensão mostra tudo do que "um homem" deveria se afastar e tudo do que ele deveria se aproximar durante a vida. Deveria ter coragem e timbre para não ser um fracalhão ou moleirão; disposição e ânimo para ser livre ao invés de ficar amuado e embezerrado; e também ter juízo para não ficar como criança ou maluco. É interessante perceber que quase todas as características tidas como "não masculinas" não estabelecem a oposição, diretamente, com as ditas femininas, mas com a criança, deixando entrever, desse modo, uma infantilização do não-masculino $e$, portanto, do próprio feminino, associação esta, àquela altura, de longa tradição. Os pólos dos quais ele tem de se afastar têm a ver com a falta de autoridade. As figuras do "fracalhão", "moleirão", "embezerrado", "amuado", "criança" e "maluco" são as de quem não tem autoridade nem sobre si mesmo tampouco sobre os outros. É este, portanto, o medo incutido desde cedo em cada criança que nascia com um pênis, o de não possuir a qualidade que o identifica da forma mais acabada: o exercício da autoridade.

Vejamos um trecho da novela Jupira, em que aparecem cenas de infância masculina e feminina:

Jupira sem que ela soubesse, não andava sem uma sentinela à vista. Era um primo seu, um sobrinho de José Luís [pai de Jupira], por nome Carlos, e a quem todos chamavam Carlito, pouco mais velho do que ela, rapazinho vivo e esperto como um diabrete. Não tendo podido parar no seminário em razão de seu gênio trêfego, indócil $e$ insubordinado, freqüentava como externo a escola de primeiras letras, onde se havia muito mal. Entretanto era excelente para servir de companheiro de brinquedos $e$ ao mesmo tempo de sentinela a sua prima durante o dia, porque de noite dormia ela fechada debaixo de chave em companhia da velha caseira de José Luís (Jupira:147).

É necessário dizer que Jupira era tão ou mais indócil que seu primo, de acordo com a narrativa. No entanto, essa 
Experiências masculinas em Bernardo Guimarães

insubordinação toma caminhos diferentes conforme o sexo das duas crianças. Carlitos não apenas não era vigiado, como ocorria com sua prima, como passou à condição de quem exerce a autoridade de vigiar e à liberdade de olhar para tudo o que se passa.

Nesses casos, que seguem a fórmula de um menino mais velho que acompanha uma menina mais nova (repetida em muitas histórias de Guimarães ${ }^{5}$ ), muitas vezes, a preocupação de vigiar vem atrelada à justificativa da proteção. Em A Garganta do Inferno, Lina também era acompanhada por seu primo mais velho, Daniel. Numa manhã, Lina relata um sonho à mãe - tinha entrado em uma caverna e lá havia encontrado muito ouro e também uma serpente que a queria engolir. A mãe então lhe responde:

- Santa Maria Eterna!... que mal sonho, minha filha!... Reza à Nossa Senhora para que arrede esse mal agouro. Isso é tentação do diabo. Lembra-te de nossa mãe Eva; também procedeu de uma serpente.

- Mas, mamãe, quanto ouro!... oh!... se eu pilho aquele ouro todo!...

- Que havias de fazer?... não havia mais gente pobre neste mundo...

- Disso estou eu certa; em poucos dias tu serias a única pobre. Mas a respeito da serpente de fogo?...

- Ora!... essa o primo Daniel mataria com a espingarda ( $A$ Garganta do Inferno:153).

Percebe-se a naturalidade com que a menina evoca a figura do primo como alguém que está sempre pronto a protegê-la. Em contrapartida, era bem diferente o que se esperava dela, segundo o narrador:

${ }^{5}$ A Voz do Pagé, Maurício, Rosaura, a enjeitada e O Seminarista. 
Conquanto tivesse toda a simplicidade e travessura de uma criança de nove anos, Lina era muito inteligente e hábil em toda a sorte de trabalhos próprios do seu sexo.

$\mathrm{Na}$ agulha, no fuso, na roda ou no tear, nada tinha que invejar às mais mestras, e em todos os misteres da casa ajudava e supria perfeitamente a sua mãe. Enfim, era uma menina completa (A Garganta do Inferno:150).

Espera-se da menina, portanto, que ela continue o que foi/é sua mãe. Que fique em casa, ao invés de andar em qualquer lugar com uma espingarda para vigiar ou proteger alguém (função freqüentemente associada ao menino ou ao jovem do sexo masculino). Tanto é que o "único motivo por que sua mãe às vezes ralhava com ela era que por vezes gostava de passear sozinha entre os rochedos (...)" (A Garganta do Inferno:150).

Além de lugares (casa/fora), de atividades (fiar/caçar) e de funções diferentes (cuidar/proteger) são também destinados às crianças e aos jovens, ao longo de seu crescimento, palavras $e$ tratamentos diversificados de acordo com o sexo, conforme as representações produzidas por Guimarães, por exemplo, as apresentações iniciais das protagonistas da história $O$ Garimpeiro - Lúcia é "formosa e interessante", Elias é "um bonito cavaleiro, um mocetão sacudido e muito bem parecido, um figurão" $(O$ Garimpeiro:11). Além da utilização do aumentativo para a designação do rapaz, as qualidades também são diferentes. Seguindo a mesma lógica, o narrador diz que naquelas paragens onde se passa o romance "os homens são robustos, ativos $e$ inteligentes $e$ as moças são bem feitas, meigas e formosas" $(O$ Garimpeiro:10). Enquanto as mulheres devem ser bonitas $e$ formosas para serem vistas, os homens são representados por características que os põem nas melhores condições de ver: com inteligência para perceber e robustez e atividade para seguir.

Um outro ponto de diferenciação entre os sexos é evidenciado pelo pronome de tratamento direcionado aos jovens rapazes. Através do pronome "Sr.", os jovens do sexo masculino 
Experiências masculinas em Bernardo Guimarães

muitas vezes são aproximados do mundo adulto. Vejamos o diálogo de Joana e sua senhora, Lúcia:

- Estás enganada, Joana, estas vão ser muito boas. Aquele moço que aqui passou outro dia, não te lembras? Aquele moço alto, de cabelo preto e anelado...

- Ah! Já sei... o Sr. Elias, aquele moço de Uberaba... (O

Garimpeiro:11)

É assim também que Lina iria falar com um moço um pouco mais velho que ela, na primeira vez em que o via, chamando-o de "senhor mancebo". ${ }^{6}$ Mais interessante ainda é ver que, nessa conversa, seu interlocutor utilizaria como pronome o termo "menina", ao se dirigir a ela (A Garganta do Inferno:161). Da mesma maneira, o narrador descreve a moça Lúcia em tom de elogio, aproximando-a da condição de menina:

Retirada na solidão da fazenda paterna, desde que saíra da escola, Lúcia crescera como o arbusto do deserto, desenvolvendo em plena liberdade todas as suas graças naturais, $e$ conservando ao lado dos encantos da puberdade toda a singeleza e inocência da infância $(O$ Garimpeiro:13-14).

Salta aos olhos também a diferença entre as vestimentas. Enquanto Lina, na ocasião do encontro com o Moço (sem designação própria durante toda a história), está sem seus "chinelinhos e com roupas arregaçadas até os joelhos", ele está com

gibão de veludo bordado de ouro, calções de seda, botas de couro polido, de cujos canos revirados pendiam borlas de ouro, e chapéu emplumado de penas de avestruz,

6 Essa forma de tratamento "Sr." para se referir aos jovens é recorrente em todas as histórias de Guimarães. 
arrimado a uma espingarda de caça (A Garganta do Inferno:160-161).

Portanto, nas representações construídas pelo autor, os jovens são "empurrados" para a vida adulta $e$ as jovens para permanecer na infância.

Essas diferenças também aparecem na descrição da indumentária de Gonçalo: "de botas com grandes esporas de prata, chapéu à banda, chicote na mão e cigarro na boca", além de "faca, garrucha e todo o trem bélico que trazia em si"; em oposição às senhoras daquela terra, onde "os corpos dos vestidos não têm serventia alguma, $e$ as mangas são verdadeiras mangas perdidas" que "elas os deixam cair sobre a saia em forma de aventais, ficando os seios a ondear livres e desafogados" $(O$ Ermitão de Muquém:40-41). Tais tipos de vestimentas masculinas sugerem uma preparação para o mundo de fora, com todas as adversidades que encerra. ${ }^{7}$

A juventude também marca diferenças de sexo no comportamento perante o público. Assim, se naqueles sertões descritos por Guimarães, homens e mulheres montavam a cavalo, os sentidos investidos neste ato e suas apreciações variavam significativamente para um rapaz ou uma moça. Enquanto Lúcia, "jovem e gentil cavaleira, que cavalgava com suma graça um lindo ginete branco", e que ganhava comentários que ressaltavam a "graça e desembaraço com que governava o cavalo e seu porte garboso e senhoril", os rapazes,

montados em lindos poldros ou em possantes mulas ajaezadas de prataria, as esporeavam pelas ruas, procurando fazer admirar as excelentes qualidades de suas cavalgaduras, e o seu desempenho e galhardia em dirigi-las (O Garimpeiro:15-16).

7 Esses modos de vestir também aparecem em Maurício (Maurício), Eduardo ( $A$ Filha do Fazendeiro), Conrado (Rosaura, a enjeitada) e Elias (O Garimpeiro). 
Experiências masculinas em Bernardo Guimarães

Salta aos olhos dos/as leitores/as a vontade desses jovens de ostentar a agilidade e a habilidade para o controle. Controle este exercido a custa de esporeadas, de violência. Seguindo essa lógica, durante a cavalhada, Elias "castigava rigorosamente" seu cavalo que o desobedecia, fato que o levou a ter "ímpetos de matar ali mesmo o cavalo a lançadas" (O Garimpeiro:23).

É também com os cavalos que esses jovens rapazes provam sua coragem, na medida em que colocam em risco sua própria vida ao desempenhar difíceis tarefas em alta velocidade. Quanto maior a velocidade do cavalo, maior a dificuldade de quem cavalga em executar outros movimentos que não sejam os destinados ao fim de se equilibrar no animal. Quanto maior a complexidade dos movimentos em situação adversa maior o valor - uma competição que promove os que se mostram mais invulneráveis. No caso das cavalhadas, eles têm a oportunidade também de exibir, através de um simulacro, sua capacidade de ameaçar a vida de outros, ao tornar públicas suas habilidades com lanças, espadas e punhais. São até mesmo aplaudidos por isso...

Chegou a hora da corrida de cabeças.

São cabeças de papelão colocadas sobre quatro postes nos cantos, e uma quinta no meio da arena. Os cavaleiros, volteando a arena a galope, cada um por sua vez tem de enfiá-las na ponta da espada; é este último passo o mais difícil, e em que poucos são felizes.

Elias, quando largou a lança, tinha nela enfiadas todas as quatro cabeças. Depois em vez de desembainhar a espada como os outros, viram-no abrir alguns botões da farda, tirar do seio um curto punhal, e dependurando-se dos arreios com a presteza e agilidade de um gaúcho, quase sumir-se debaixo do cavalo, e depois reaparecer com a cabeça cravada na ponta do punhal. Os aplausos e os foguetes retumbaram por todos os lados (O Garimpeiro:23).

Essas práticas são, na realidade, correlatas de discursos que naturalizam a prerrogativa de colocar-se em perigo como uma 
característica intrínseca ao masculino, como presente no comentário do narrador que, assustado, descrevia uma menina fazendo o que os homens temeriam:

Além do arroio, havia uma espécie de lapa, formada pela saliência de um enorme penedo que lhe servia de teto, $e$ cujas paredes eram formadas por arbustos emaranhados, por uma rede impenetrável de cipós e trepadeiras. A entrada era pequena e a lapa escura e profunda. Qualquer homem teria medo de penetrar ali; mas, Lina ansiosa $e$ anelante, dirigiu-se resolutamente para ela (A Garganta do Inferno:161).

Através de um jogo antitético, discursos naturalizam a força física como atributo masculino e a fragilidade como feminino:

Assim todo aquele ouro que robustos braços, com insano trabalho, gastaram anos a extrair das entranhas da terra, em duas ou três horas uma frágil moça sepultou-o outra vez no seio dela (A Garganta do Inferno: 191).

O fato é que esses discursos e essas práticas culturais, saturados no cotidiano, vão produzindo dicotomias que marcam profundamente a subjetividade, vão produzindo sujeitos que se sentem compelidos a se distanciarem. ${ }^{8}$ Após esse processo de socialização, os jovens, bombardeados por mensagens e práticas prescritivas, se tornarão adultos diferenciados pelo sexo. Segundo Bourdieu (1995:156-157), o corpo adulto é uma fabricação política e ética e, por isso,

a educação fundamental é fundamentalmente política: ela tende a inculcar maneiras de portar o corpo (...) que estão prenhes de uma ética, de uma política, de uma cosmologia.

\footnotetext{
8 Parece ocorrer o mesmo nos dias atuais, como mostram inúmeras pesquisas. Entre outras, ver Louro (1997).
} 
Experiências masculinas em Bernardo Guimarães

É assim que Lina e seu Moço, ao se amancebarem, reservam (e conservam) papéis bem distantes para um e outro. Em conversa com o companheiro, Lina queixava-se de saudades da mãe:

- Mas então, nunca mais devo vê-la?... por piedade, pelo nosso amor, deixa-me ir abraçá-la; não me demorarei muito; ela morrerá de saudade se não me enxergar mais.

- Não te inquietes, minha querida; hás de ver tua mãe, eu te prometo; mas hás de vê-la de rosto erguido, e a fronte serena. Para esse fim é preciso legitimar o nosso amor, casando-nos; é isso o que pretendo fazer, minha adorada Lina.

Um sorriso de inefável felicidade brilhou nos lábios da menina; sem dizer palavra atirou-se nos braços do mancebo, o cobriu de beijos e chorou de prazer (A Garganta do Inferno:162).

Se por um lado, diante da amada, o Moço parece seguro ao ocupar o papel de um (quase) adulto, por outro, sua resposta à indagação de Lina - "quando será isso? Porque não pode ser já?" - revela que a relação entre eles está inserida numa trama maior, na qual reaparecem a interdição da família e a explicitação de um lugar de dependência no qual o jovem ainda vivia:

- Porque por ora meu pai não quer consentir; quer que me case com alguma rica e ilustre fidalga, como se eu não tivesse riqueza $e$ fidalguia bastante para repartir com a escolhida de meu coração.

- Oh! como é bom para mim, exclamou Lina, apertando-o de novo nos braços; mas teu pai?... como te arranjarás com ele?... tenho medo que nunca queira consentir...

- Deixa por minha conta, menina; eu saberei vencê-lo; mas é preciso que tenhas paciência e esperes ainda (A Garganta do Inferno:163). 
Assim, se a filha permanece ligada à mãe, o filho terá literalmente de "vencer o pai" para se tornar senhor do seu destino e, quase literalmente, de sua amada. Ao noivo cabe empreender a guerra, à noiva é reservada a incumbência de esperar e ter paciência. Afronta que tem por fim, se bem aventurada, o que nem sempre é o caso, fazer valer a autoridade do homem que está prestes a surgir para escolher livremente o que quer e o que não quer.

\section{Masculinidade bélica}

A luta contra a vontade do pai parece ser uma prévia do que o mundo reserva para mais tarde ao jovem do sexo masculino do século XIX. Um mundo cheio de outros homens, desta vez adultos, desejosos de fazer prevalecer suas próprias vontades sobre as dos outros. Portanto, desordenadamente e de forma muitas vezes velada, os jovens que passaram por tal processo de masculinização parecem ser compelidos, ao longo de seu crescimento, a desenvolverem preocupações que se distribuem em três direções que se entrecruzam permanentemente: com a coragem, com a liberdade e, sobretudo, com o exercício da autoridade.

No entanto, se os arranjos possíveis entre essas três direções podem ser variados, um deles parece se sobressair, convocando um quarto elemento que também é crucial para a pauta de preocupações dessa masculinidade: Coragem evoca Ameaça; Ameaça convoca Respeito; Respeito concede Autoridade; Autoridade garante Liberdade. $\mathrm{O}$ quarto alvo da preocupação masculina no XIX está relacionado ao respeito. Mas respeito de quem? E que ameaça é essa? Respeito dos outros homens que convivem no entorno de um determinado homem; dos que

9 Sobre a questão do Pai na psicanálise, cf. Freud (1980) e Lacan (2005). 
tiveram o mesmo tipo de criação; dos que aprenderam as regras do jogo e que foram estimulados desde cedo a jogá-lo. ${ }^{10}$

O que se disputa nesse jogo é fazer prevalecer o exercício de sua vontade sobre a dos demais jogadores. No entanto, a condição para participar desse jogo depende antes da autorização dos que já participam dele. E é aí que está a ameaça permanente. A qualquer momento os pares podem deixar de fora aquele que não cumprir os pré-requisitos que a maioria considera básicos. A ameaça constitui-se mesmo em um dos principais objetivos e em condição preliminar para participar desse jogo: ter o poder de tentar fazer com que o jogador adversário não seja ouvido, fazer com que ele, em última instância, não chegue sequer a participar do jogo. Portanto, a preocupação em alcançar, e manter, o respeito dos demais participantes ergue-se como uma necessidade indispensável para cada jogador, que passa a se sentir, a todo o instante, na obrigação de dar provas de que merece estar no páreo.

Essa exigência parece ter sido o motivo do fracasso social do jovem Gonçalo, personagem principal de O Ermitão de Muquém. A necessidade de dar provas aos outros homens passou a ocupar um lugar central na vida do rapaz. O narrador justifica tal circunstância, primeiro, pela má educação que recebera durante a infância e, depois, pela morte dos pais antes que completasse vinte anos.

Em todos os maus lugares, onde quer que houvesse uma orgia, um batuque, uma algazarra qualquer, podia-se jurar que lá se achava Gonçalo puxando barulho, provocando desordens, só para ter ocasião de ostentar a bravura e fazer sentir a algum desgraçado o peso de seu braço de ferro. Nisto consistia todo o seu orgulho, toda a sua glória. Quando em Goiás aparecia algum desses valentões afamados, com um desses apelidos extravagantes que por

${ }^{10}$ Bourdieu (1995:163) chama atenção para a importância dos jogos na dimensão da socialização masculina, designando-os "jogos de dominação". 
si só fazem tremer, como Veneno, Jacaré, Tiracouro, Ganguçu, etc., bem barbudo, vestido de couro, armado até os dentes, lá ia Gonçalo procurá-lo e não sossegava enquanto não achasse ocasião de quebrar-lhe a proa (Ermitão de Muquém:34).

Apesar de todos esses desvarios, o rapaz acabava conquistando o respeito e até mesmo a estima de muitos.

Demais, Gonçalo tinha por si grande número de parceiros, vadios e bandidos como ele, que o temiam $e$ respeitavam, $e$ com os quais contava em ocasião de aperto. Era uma malta de rapazes ociosos e devassos, da qual ele, por sua superioridade em forças, destreza, riqueza e generosidade, era o chefe natural.

Posto que temido como uma onça e respeitado entre seus camaradas pela sua valentia, Gonçalo não deixava de ser estimado, $e$ em qualquer folguedo a sua presença era indispensável, pois era o companheiro mais alegre $e$ folgazão que se conhecia (Ermitão de Muquém:36).

Quando as oportunidades de dar provas de seu poder de ameaça se esgotam, Gonçalo as cria. E será este o motivo de sua desgraça e a de outros.

A vida tranqüila que ia passando, sem achar ocasião ao menos de dar uns murros ou uns pontapés, o enjoava por tal sorte, que estava resolvido a ir viajar pelos sertões em busca de quanto valentão e facínora afamado por aí houvesse, medir suas forças com eles, matá-los todos $e$ trazer suas orelhas de mimo ao capitão-mor. O destino, porém, ajeitou as coisas por tal modo que não foi preciso a Gonçalo sair de Goiás para que fossem completamente satisfeitos os seus desejos.

Entre os comparsas de Gonçalo havia um que, além de ser seu particular amigo, era o único que ousava rivalizar com ele em força e destreza. Era um rapaz por nome Reinaldo, 
Experiências masculinas em Bernardo Guimarães

robusto $e$ bem feito, e geralmente estimado por sua franqueza e lealdade, e que ainda não se tinha deixado inteiramente eivar do espírito de desordem e devassidão dos seus companheiros. Nos exercícios de luta, esgrima $e$ outros era o que dava mais trabalho a Gonçalo, e por vezes acontecia ficar indecisa a vitória. Como era ainda muito moço, tinha esperança de um dia igualar, senão exceder a seu amigo em vigor e agilidade (Ermitão de Muquém:38).

Gonçalo decide, então, procurar intriga com o próprio amigo numa festa organizada pelo respeitado ferreiro do arraial, Mestre Mateus, fazendo um jogo de sedução com Maroca, namorada de Reinaldo. O diálogo a seguir se dava entre o protagonista e o dono da festa:

- Agora sim, compadre, sou da festa; a Maroca está aí, vai tudo bem. E o Reinaldo, onde está ele? Não veio?...

- Não enxergas!... Olha, lá está ele naquele canto, e por sinal que está hoje triste e de viseira fechada, não sei porquê.

- Bem! Lá o vejo, disse Gonçalo, em cujos olhos reluzia um prazer satânico, e continuou resmungando entre si: - Bem! Muito bem! Aqui sim! Tenho uma linda menina a quem posso fazer a corte, $e$ ao lado dela um valentão de primeira ordem, a quem farei abaixar o topete. Ah! Reinaldinho, meu amigo, eis aqui uma bela ocasião de mostrar, sem ser por brincadeira, qual dos dois é mais valente, o tigre ou a onça, $e$ isto sem quebra de nossa amizade; para teu ensino quebrar-te-ei bem as costelas diante de toda esta gente, $e$ nem por isso deixaremos de continuar a ser bons amigos como dantes. Não serás o primeiro amigo a quem dou uma destas proveitosas lições (Ermitão de Muquém:44).

O desfecho dessa história foi bastante trágico para os três envolvidos. Gonçalo realmente seduzira Maroca e conseguiu convencê-la a sair da festa às escondidas consigo. Reinaldo, ao se dar conta disto, sai à procura dos dois e os alcança ainda na 
estrada, onde travaram luta com facas empunhadas. Reinaldo é morto; Maroca enlouquece ao presenciar o assassinato; Gonçalo sobrevive a custo e é obrigado a fugir para as matas povoadas de tribos indígenas, além de ser condenado a conviver com o peso da culpa.

Com as mãos manchadas no sangue de um amigo a quem perfidamente assassinara, com a alma atassalhada de remorsos e em um sombrio desespero, vagava a esmo pelos desertos, esperando morrer às garras de alguma fera ou entre as mãos dos gentios, se não sucumbisse à mortal tristeza que por dentro o corroia (Ermitão de Muquém:78).

Outras dimensões dessa masculinidade bélica aparecem no conto A Dança dos Ossos. À beira do fogo, no início da noite, alguns homens conversam às margens do Rio Parnaíba. Na roda exclusivamente masculina, apartada das mulheres, temos a oportunidade de surpreender, em pleno funcionamento, a lógica do jogo descrito acima. São nessas rodas que os homens se medem pelo olhar dos outros.

Numa confusão entre os dias da semana, o velho Cyrino, que tomava a palavra para contar um caso, exclama:

- Sábado!... que me diz? E eu, na mente que hoje era sextafeira!... oh! senhorinha! Eu tinha precisão de ir hoje ao campo buscar umas linhas que encomendei para meus anzóis, e não fui, porque esta minha gentinha de casa me disse que hoje era sexta-feira... e esta!... e hoje, com esta chuva, era dia de pegar muito peixe... Oh! senhorinha!... gritou o velho com mais força.

A este grito apareceu, saindo de um casebre vizinho, uma menina de oito a dez anos, fusca e bronzeada, quase nua, bocejando e esfregando os olhos; mas que mostrava ser uma criaturinha esperta e viva como uma capivara. 
Experiências masculinas em Bernardo Guimarães

- Então, senhorinha, como é que tu vais-me dizer que hoje era sexta-feira?... ah! Cachorrinha! Deixa-te estar, que amanhã tu me pagas... então hoje que dia é?...

- Eu também não sei, papai, foi a mamãe que me mandou que falasse que hoje era sexta...

- É o que tua mãe sabe te ensinar; é a mentir!... deixa, que vocês outra vez não me enganam mais. Sai daqui: vai-te embora dormir, velhaquinha!

Depois que a menina, assim enxotada, se retirou, lançando um olhar cobiçoso sobre umas espigas de milho verde que os caboclos estavam a assar, o velho continuou:

- Veja o que são artes de mulher! A minha velha é muito ciumenta, $e$ inventa todos os modos de não me deixar dar um passo fora daqui. Agora não me resta um só anzol com linha, o último lá se foi esta noite na boca de um dourado; $e$, por culpa dessa gente, não tenho maneiras de ir a matar um peixe para meu amo almoçar amanhã! (A Dança dos Ossos:212-213).

Os gritos do velho, suas repreensões e seus insultos dirigidos à filha (e em extensão à sua esposa) evidenciam a exibição, aos olhos dos homens que ali estavam, de sua autoridade, de sua voz de mando, de sua posição de comando. Naquele momento, ele enviava uma mensagem velada aos outros homens - gosto pela autoridade e sua prerrogativa. Usando a filha, ele mostra que tem capacidade de produzir submissão. Além disso, a passagem não deixa de elucidar a desimportância da infância naquele contexto, bem como a falta de cuidado masculino com as crianças, já que não seria dele a incumbência de cuidar, mas sim de proteger $e$, portanto, repreender.

Também de forma bastante indireta, Cyrino mostra aos seus pares o gosto pela liberdade, ao lamentar (num falso lamento) que sua mulher tente prendê-lo. Dessa forma, se promove aos olhos dos outros homens, afirmando sua disposição de contrariar a vontade de outrem, no caso, a de sua "velha" de mantê-lo perto de casa. Afirma, assim, sua autonomia ao lançar a idéia de que, se 
não tivesse sido enganado, sairia ${ }^{11}$, mesmo a contragosto de alguém que permanece ao seu lado e que, portanto, se submete a ele (fato que reforça sua posição de autoridade legítima perante os olhos e ouvidos dos presentes). Esse trecho não deixa de revelar, ainda, o estado de dependência mais elementar na qual se encontra esse tipo masculino para com a mulher.

Mas ele também sente necessidade de dar provas de sua coragem ao longo da narração. Embora tenha confessado que numa ocasião teve medo, revela também que sentiu vexame por tê-lo experimentado. E termina afirmando que o enfrentou, afinal.

Quando montei no meu burro para vir-me embora, já o sol estava baixinho; quando cheguei na mata, já estava escuro; fazia um luar manhoso, que ainda atrapalhava mais a vista da gente.

(...) Meu coração deu uma pancada e a modo que estava me pedindo que não fosse adiante. Mas fiquei com vergonha de voltar. Pois um homem, já de idade como eu, que desde criança estou acostumado a varar por esses matos a toda hora do dia ou da noite, hei-de agora ter medo? De que? (A Dança dos Ossos:217).

Ele também afirma aos seus ouvintes sua capacidade de dominar, ao evocar o episódio em que seu burro "estava a refugar e a passarinhar numa toada" que o incomodava, mas que, "a

\footnotetext{
${ }^{11}$ Aliás, são as personagens masculinas que saem com freqüência enquanto as femininas os esperam. Cyrino assim descreve a sua chegada em casa: "Quando a minha velha, de manhã cedo, foi abrir a porta, me encontrou no terreiro, estendido no chão, desacordado, e o burro selado perto de mim" (A Dança dos Ossos:222). São os homens que viajam com freqüencia, são eles que se ausentam enquanto suas amantes os esperam: Moço que fazia repetidas ausências para Vila Rica (A Garganta do Inferno); Conrado que roda províncias negociando muares (Rosaura, a enjeitada); Eduardo que tem esta mesma profissão (A Filha do Fazendeiro); Elias que parte para o garimpo $(O$ Garimpeiro)... Foram essas viagens que fizeram com que o Moço (A Garganta do Inferno) e Eduardo (A Filha do Fazendeiro) encontrassem outras mulheres e desfizessem o compromisso com suas prometidas.
} 
Experiências masculinas em Bernardo Guimarães

poder de esporas, sempre foi varando" o caminho (A Dança dos Ossos:218). Também corrobora sua coragem ao afirmar, com orgulho, que tem intimidade com o álcool, uma vez que os homens, muitas vezes, o utilizam como forma de hierarquização: é superior aquele que bebe mais, o que permanece em sanidade diante do excesso do álcool que vem justamente desafiar esta sanidade. Por isso ele diz ufano: "pode $\mathrm{Vm}$. ficar certo de que, quando eu tomo um gole, aí é que minha vista fica mais limpa e o ouvido mais afiado" (A Dança dos Ossos:218).

Essa demonstração de coragem, por outro lado, pode aparecer algumas vezes através da aproximação do homem ao mundo animal, por parte do narrador:

Joaquim Paulista tinha uma paixão louca pela Carolina; mas ela andava de amizade com um outro camarada, de nome Timóteo, que a tinha trazido de Goiás, ao qual queria muito bem. Vai um dia, não sei que diabo de dúvida tiveram os dois, que a Carolina se desapartou do Timóteo $e$ fugiu para a casa de uma amiga, aqui no campo. Joaquim Paulista, que há muito tempo bebia os ares por ela, achou que a ocasião era boa, e tais artes armou, tais agrados fez à rapariga, que tomou conta dela. Ah! Pobre rapaz!... se ele adivinhasse, nem nunca teria olhado para aquela rapariga. O Timóteo, quando soube do caso, urrou de raiva e de ciúme (A Dança dos Ossos:234).

Os "urros" de raiva, como fazem os animais, dados por homens nas situações mais diversas, estão presentes em quase todas as histórias de Guimarães. Um urro, a um só tempo, demonstra força e espanta alguma possível ameaça. Ameaça que, no caso elucidado pelo excerto anterior, parece ter a ver com a provável perda da honra. É como se Timóteo tivesse perdido um jogo, cujo objeto de disputa é uma mulher. Jogo onde a perda é humilhante na medida em que ela pode levar o derrotado a perder a admiração e a consideração dos outros homens, que têm o poder de vetar sua participação nos jogos de dominação. 


\section{Considerações finais}

As trajetórias de personagens de sexo masculino de alguns romances escritos no XIX evidenciam que há, na verdade, um processo de masculinização. A literatura analisada permite entrever traços de um padrão de masculinidade que se quis hegemônico no Brasil do final do século XIX, demonstrada na desmedida ambição sexual presente na voz masculina do eu-lírico da poesia O Elixir do Pagé (1875), bem como o belicismo competitivo estimulado, e realizado, junto ao processo de constituição da identidade masculina das personagens, valores estes cultuados naquele contexto em que um determinado modelo de masculinidade imperava. Tais comportamentos são típicos de homens que participam de uma dinâmica identitária que se sustenta, em última instância, na busca pela admiração dos pares que, por sua vez, participam também desta mesma lógica.

Verificamos também que no mundo masculino do século XIX, captado pela ótica de Bernardo Guimarães, essa busca pela admiração dos outros homens está vinculada à questão da legitimidade para o exercício do poder. Alcança a legitimidade para o exercício do poder aquele que consegue criar a ilusão de dominar um símbolo que os demais valorizam.

Os bens simbólicos que as sociedades produzem não são ilimitados. Ora, a legitimidade do poder é um bem particularmente raro e asperamente disputado. Constitui, muito em especial, o objeto dos conflitos entre dominantes e dominados (Baczko, 1985:310).

Logo, se considerarmos a valentia e a atividade sexual como símbolos valorizados pelos homens do período, entenderemos porque se importavam tanto em criar a ilusão de terem essas prerrogativas em detrimento dos demais. Talvez seja interessante pensar, em outra ocasião, nas implicações dessa concepção nas relações estabelecidas entre esses homens e a feminilidade no período. 
Experiências masculinas em Bernardo Guimarães

No entanto, o mesmo autor nos remete continuamente às indefinições das fronteiras que separam os comportamentos percebidos como "masculinos" $e$ "femininos" $e$, mesmo, às angústias vivenciadas pelos personagens sobre a constituição do sujeito masculino e feminino. Ao perguntar quando o rapaz vai se tornar um "homem" ou ao construir personagens femininas que demonstram ter comportamentos tipicamente masculinos, o autor nos remete ao contexto sócio-cultural de constituição dos sujeitos. Do mesmo modo, os personagens construídos e dados a ler na obra literária de Guimarães não deixam continuamente de nos remeter às angústias pessoais que acompanham as crianças $e$ os jovens na estruturação de suas identidades de gênero num mundo em que a lógica dos adultos tenta continuamente impor escolhas que, em última instância, refletem também suas próprias angústias, medos e incertezas. No entanto, mesmo diante desse cerceamento, as crianças e, sobretudo, os jovens fazem escolhas, defendem suas convicções $e$ investem em projetos de futuro. Como na vida real, às vezes as escolhas são trágicas, os meios são violentos, os projetos malogrados. Outras vezes não.

\section{Referências bibliográficas}

Alves, Virgínia Santos. Práticas de leitura, escrita e educação no século XIX a partir da obra de Machado de Assis (1870-1880). Dissertação de Mestrado em Educação, UNINCOR, 2007.

BACZKO, Bronislaw. Imaginação social. Enciclopedia Einaudi: AntroposHomem. Lisboa, Imprensa Nacional Casa da Moeda, 1985.

BOURDIEU, Pierre. A Dominação Masculina. Educação \& Realidade. 20(2), jul./dez., 1995, pp.33-184.

CHARTIER, Roger. O mundo como representação. In: À beira da falésia: a história entre incertezas $e$ inquietude. Porto Alegre, Ed. Universidade/UFRGS, 2002, pp.61-81.

DALCIN, Talita Banck. 'Palmatoando' as fontes: os usos dos castigos físicos em nome da disciplinarização e da ordem nas escolas paranaenses da segunda metade do século XIX. In: OlIVIERA, Marcus 
Aurélio Taborda. Educação e corpo na escola brasileira. CampinasSP, Autores Associados, 2006, pp.71-92.

FREUD, S. Edição Standard Brasileira das Obras Completas. Rio de Janeiro, Imago, 1980. . Moisés e o monoteísmo: três ensaios. vol. XXIII, 1937. . Dostoievski e o parricídio. vol. XXI, 1928. . Totem e tabu. vol. XIII, 1913.

KoRIN, Daniel. Novas perspectivas de gênero em saúde. Adolescencia Latinoamericana, vol. 2, n 2, março de 2001, pp.67-79.

LACAN, J. Nomes-do-pai. Rio de Janeiro, Zahar, 2005.

LOPES, Eliane Marta Teixeira. História da Educação e Literatura: algumas idéias e notas. Educação em Revista, $\mathrm{n}^{\circ}$ 27, Belo Horizonte, FAE/UFMG, julho de 1998, pp.29-34.

LOURO, Guacira Lopes. Gênero, Sexualidade e Educação: Uma perspectiva pós-estruturalista. Petrópolis, Vozes, 1997, pp.57-87.

MAGALDI, Ana Maria Bandeira de Mello. Mulheres no mundo da casa: imagens femininas nos romances de Machado de Assis e Aluízio Azevedo. In: BRUSCHINI, Cristina \& COSTA, Albertina de Oliveira. Entre a virtude e o pecado. Rio de Janeiro, Rosa dos Tempos; São Paulo, Fundação Carlos Chagas, 1992, pp.57-88.

Welzer-LANG, Daniel. Os homens e o masculino numa perspectiva de relações sociais de sexo. In: SCHPUN, Mônica R. Masculinidades. Santa Cruz do Sul, Boitempo, 2004, pp.107-128.

\section{Fontes $^{12}$}

GuimarÃEs, Bernardo. A Voz do Pagé. In: CRUz, Dilermano. Bernardo Guimarães (Perfil bio-bibliografico). Belo Horizonte, Imprensa Oficial, 1914 [Peça apresentada em 1860]. 1966 [1869]. O Ermitão de Muquém. Rio de Janeiro, Edições de Ouro, . O Seminarista. São Paulo, Ática, 1980 [1872]. . O Garimpeiro. São Paulo, Ática, 1980 [1872].

${ }^{12}$ As fontes estão organizadas de acordo com a ordem cronológica de suas primeiras edições. 
Experiências masculinas em Bernardo Guimarães

Histórias e Tradições da província de Minas Geraes. Rio de Janeiro, Civilização Brasileira, 1976. [1872. Reunidas neste volume: "Jupira", "A Filha do Fazendeiro" e "A Cabeça de Tiradentes"]. . Índio Affonso. Rio de Janeiro, Garnier, sd. [1873].

Lendas e Romances. Rio de Janeiro, Garnier, sd. [1873.

Reunidas neste volume: "Uma História de Quilombolas", "A Garganta do Inferno" e "A Dança dos Ossos"]. . A escrava Isaura. São Paulo, Ática, 1980 [1875].

. Maurício ou Os Paulistas em São João D'El Rey. Rio de Janeiro, F Briguiet \& CIA, 1941 [1877]. [1883]. Rosaura, a enjeitada. São Paulo, Saraiva, s.d. 2 volumes . Poesia erótica e satírica (1852-1883). Rio de Janeiro, Imago, 1992 (org. Duda Machado). 